\title{
Protodrilus (Protodrilidae, Annelida) from the southern and southeastern Brazilian coasts
}

\author{
Maikon Di Domenico • Alejandro Martínez • \\ Paulo da Cunha Lana $\cdot$ Katrine Worsaae
}

Received: 23 November 2012/Revised: 19 April 2013/Accepted: 22 May 2013/Published online: 21 June 2013

(C) Springer-Verlag Berlin Heidelberg and AWI 2013

\begin{abstract}
Protodrilus corderoi, Protodrilus ovarium n. sp. and Protodrilus pythonius n. sp. are reported from beaches in southern and southeastern Brazil and described combining live observations with light and electron scanning microscopy studies. Protodrilus corderoi is redescribed from new collections at the type locality, and a neotype for the species is assigned since the original type material no longer exists. New information on reproductive organs, segmental adhesive glands and unpigmented ciliary receptors as well as morphometrics is provided. Protodrilus ovarium n. sp. and P. pythonius n. sp. are formally described. Protodrilus ovarium n. sp. is diagnosed by the presence of separated lateral organs on segments 7-12, three spermioducts of segments 10-12 and salivary glands in segments 1-9. Protodrilus pythonius n. sp. is defined by
\end{abstract}

Communicated by H.-D. Franke.

M. Di Domenico $(\bowtie) \cdot$ P. C. Lana

Benthic Laboratory, Centre for Marine Studies,

Universidade Federal do Paraná, Curitiba, Brazil

e-mail: maik2dd@gmail.com

P. C. Lana

e-mail: lana@ufpr.br

M. Di Domenico

Zoological Museum "Prof. Dr. Adão José Cardoso",

Biological Institute, University of Campinas (UNICAMP),

Charles Darwin, s/n,6109, Campinas, São Paulo 13083-863,

Brazil

\author{
A. Martínez · K. Worsaae \\ Marine Biological Section, Department of Biology, \\ University of Copenhagen, Strandpromenaden 5 , \\ 3000 Helsingør, Denmark \\ e-mail: amartinez@bio.ku.dk \\ K. Worsaae \\ e-mail: kworsaae@bio.ku.dk
}

the presence of separated lateral organs on segments 7-16, long pygidial lobes and body tapering toward the pygidium. The distribution of the different species in more or less spacious habitats seems to be correlated with their gross morphology. Protodrilus pythonius n. sp., with relatively long and wide body and long palps with ciliary bands, was collected in very coarse sandy sediments at a reflective sheltered beach. Conversely, $P$. corderoi and $P$. ovarium n. sp., both possessing more slender bodies with shorter, less ciliated palps, occurred in medium-coarse, well-sorted sediments in the more energetic swash zone of exposed intermediate-reflective beaches. The finding of $P$. pythonius and $P$. corderoi in nearby beaches corroborates other studies showing a higher morphological variability among species in different habitats within the same geographical area than among species in the same habitat in different geographical areas.

Keywords Protodrilida $\cdot$ Epidermal glands $\cdot$ Southern Brazil $\cdot$ Sandy beaches $\cdot$ Meiofauna $\cdot$ Barcoding

\section{Introduction}

Protodrilidae Czerniavsky (1881) is one of the simplest looking groups of annelids in terms of their external morphology showing only two appendages, no parapodia, no chaetae or obvious segmentation. The entire group consists of 35 described noodle-like species bearing paired palps and pygidial lobes as the only conspicuous morphological features. The family consists of the genera Protodrilus (Hatschek 1880) and Parenterodrilus Jouin, 1979 (Jouin 1992) and has been grouped with Protodriloididae and Saccocirridae in the clade Protodrilida (Purschke and Jouin 1988; Purschke 1990, 1993). Protodrilida has never been recovered with molecular 
data, and the position of the three families in Annelida is still pending (Struck 2011). Despite their relatively high species diversity, Protodrilidae still represent a taxonomical challenge due to their limited morphological diversity and lack of structures such as chaetae or jaws (Von Nordheim 1989). Several of the species are only poorly described (Kirsteuer 1966; Langerhans 1880; Wieser 1957), and many of the records possibly represent potentially new species (Kirsteuer 1967; Jouin 1970a; Bailey-Brock et al. 2010), all pointing to the need of a major revision of the group before we can understand their evolutionary and biogeographical history (Worsaae and Kristensen 2005; Martínez et al. 2013).

The highest diversity of Protodrilus is known from the Eastern Atlantic and Mediterranean Sea (18 species, $51 \%$ of the 35 described species). In contrast, only five species are known from the Western Atlantic: Protodrilus corderoi du Bois-Reymond, 1948, from São Sebastião Island (Brazil) and possibly Dominica (Caribbean Sea), P. gelderi Riser, 1997 from Massachusetts Bay (USA), and $P$. smithsoni, P. draco, and P. hochbergi (Martínez et al. 2013) from Panama and Belize, as well as a few records to genus level are reported from the Western Atlantic (Kirsteuer 1967; Di Domenico et al. 2009; Ruebush 1939). More recent surveys of the interstitial fauna from the Western Atlantic suggest, however, that such diversity trends reflect a substantial regional sampling bias, rather than the biogeographic patterns of this group (Martínez et al. 2013).

Species of Protodrilus are restricted to the interstitial environment of marine sediments, spanning from fine sand to gravel (Von Nordheim 1989). The body shape reflected in the reasonable ecological uniformity by homogeneous body plan, consisting of a cylindrical elongated body with a midventral ciliary band, for gliding and a head region with prostomial paired palps and a ventral muscular pharynx for collect deposit particles among the sediment grains. Adhesive pygidial lobes and segmental glands impede the animals from being washed out of the sediment and lateral organs, with species-specific arrangement, are involved in sperm transference (Jouin 1970b; Purschke and Jouin 1988; Westheide 2008). Despite this apparently uniform body plan, some traits (e.g. palp length, epidermal glands arrangement or ciliary patterns on body and palps) vary among groups of species. The morphological differences are found among species dwelling in different habitats in the same geographic region, rather than among similar habitats in different geographic areas (Martínez et al. 2013). This variability among habitats may reflect important speciation events in the early evolutionary history of meiofaunal organisms (Sterrer 1972, 1973), which warrants more intensive sampling, and the combination of detailed morphological studies with microhabitat characterization in future studies.

One of the harshest interstitial environments is represented by the swash zones of intermediate-reflective beaches, due to the breaking plunge-from surging wave types (McLachlan and Turner 1994). These waves produce high turbulence and hydraulic flow in the sediment, but also favor oxygenation, absence of a redox layer and constant organic matter input among the grains (Short 1996). Despite that turbulence, the swash zone of reflective beaches seems to provide an ideal habitat for several welladapted interstitial groups, including several Protodrilus (Di Domenico et al. 2009; McLachlan 1985, 1990). The presence of adhesive glands, as well as special epidermal glandular or skeletal structures, foraging strategies and escape motility, is the most common adaptation to such extremely turbulent environments (Bush 1968; DelamareDeboutteville 1960; Boaden 1995; Giere 2009; Jouin 1970b; McLachlan 1988).

We describe herein three species of Protodrilus from intermediate-reflective and reflective beaches from the south and southeastern coasts of Brazil, of which are two new to science, and the previously reported Protodrilus corderoi du Bous-Reymond, 1948, is redescribed. Live observations are combined with detailed light microscopy and scanning electron microscopy studies, as well as environmental granulometrical and morphodynamic data. Barcoding cytochrome $c$ oxidase subunit I reference sequences are provided to further support our results and facilitate future re-identification of these species. A neotype for $P$. corderoi is designated, since the type material of the species no longer exists.

\section{Materials and methods}

\section{Sampled localities}

Seven beaches along the southeastern and southern coasts of Brazil $\left(20^{\circ} \mathrm{S} 42^{\circ} \mathrm{W}-27^{\circ} \mathrm{S} 49^{\circ} \mathrm{W}\right)$ were surveyed (Fig. 1): Estaleiro, Estaleirinho and Barra Velha (Santa Catarina State), Toque-Toque, Tombo and Feiticeira (São Paulo State) and Barra da Tijuca (Rio de Janeiro State). Intermediate to reflective beaches were preferred for intensive sampling as they showed the highest Protodrilus diversity in previous studies (Di Domenico et al. 2009). These beaches are exposed, semi-exposed and sheltered to swells from the east and southeast and display medium-coarse grain sizes, high slopes, embayment between headlands, absence of redox layers and high hydraulic flux in the swash zone. The local tidal regime consists of microtides of discontinuous semidiurnal periods with mean amplitude of $0.8 \mathrm{~m}$ (Schettini et al. 1999; Carvalho et al. 1996), occasionally influenced by storms, which can raise the sea level ca. $1 \mathrm{~m}$ above astronomical tides (Carvalho et al. 1996; Schettini et al. 1999). Most beaches are exposed and dominated by waves due to NS orientation of the coastline 

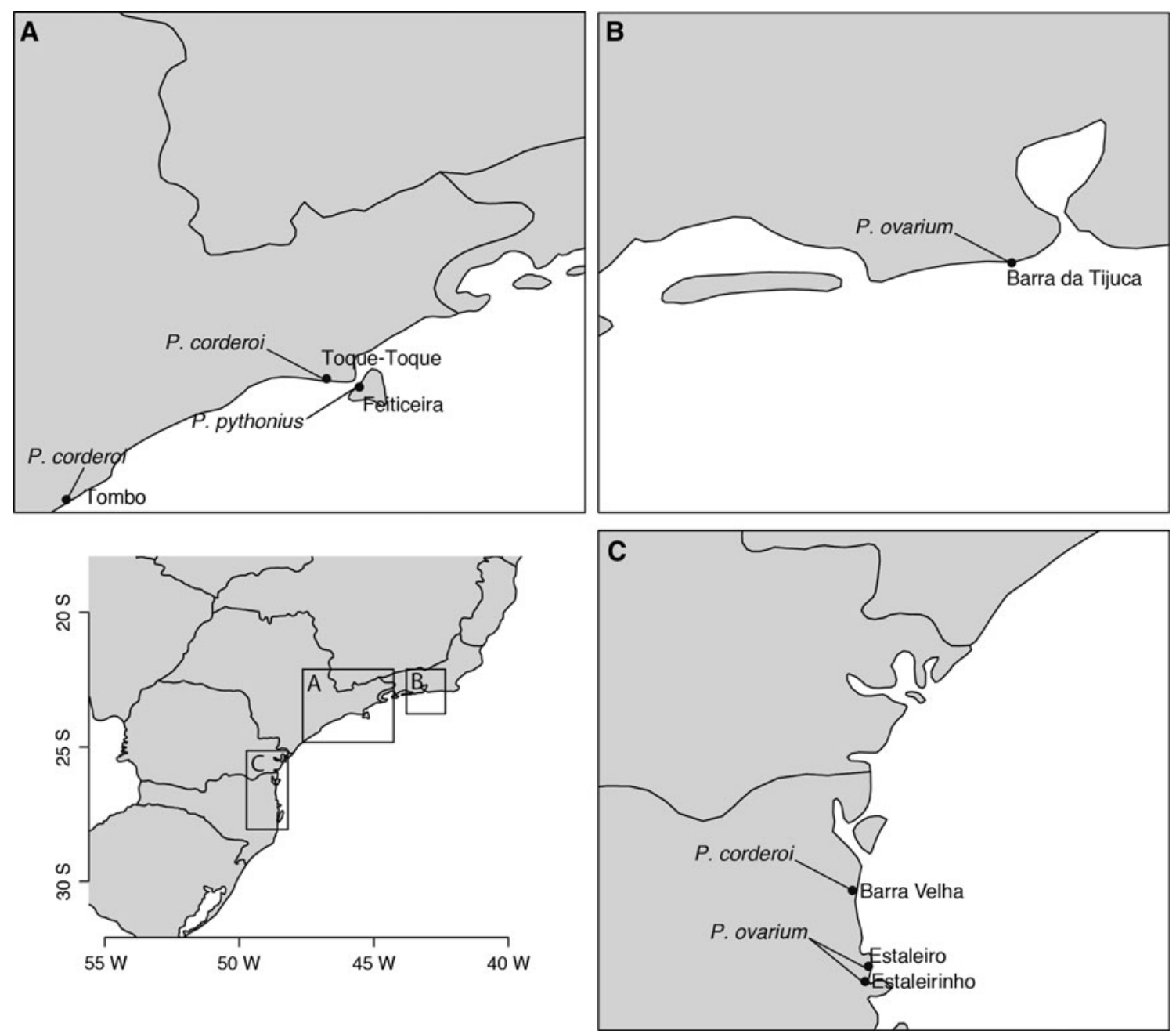

Fig. 1 Map of the sampled localities and species found. a São Paulo beaches, Tombo ( $P$. corderoi), Feiticeira ( $P$. pythonius) and ToqueToque ( $P$. corderoi); b Rio de Janeiro beach, Barra da Tijuca

(P. ovarium); c Santa Catarina Beaches, Estaleirinho ( $P$. ovarium), Estaleiro (P. ovarium) and Barra Velha $(P$. corderoi $)$

and NE-SW waves system or winds prevailing in the region (Klein and Menezes 2001; Barros et al. 2001). Four predominant sea states were identified in the region: (1) sea winds from east-northeast (ENE), predominant throughout the year; (2) sea winds from south-southeast (SSE) (3) southwest and (4) east swells. Southwest swells and waves from the east occur during the winter and spring due to increased frequency and intensity of the passage of frontal systems in the region (Alves and Melo 2001). Beach sediments were collected manually or by snorkeling from oxygenated surface layers, including three replicates for granulometric analyses.

\section{Morphological observations}

Animals were extracted by the $\mathrm{MgCl}_{2}$ decantation technique through a $63-\mu \mathrm{m}$ mesh (Higgins and Thiel 1988), sorted alive and documented with a Canon PowerShot S45

camera mounted on a Olympus SZH-ILLD light microscope.

Light microscopy studies (LM) were performed on specimens fixed in paraformaldehyde $(24 \mathrm{~h}$, followed by 6-7 rinses of PBS buffer over $6 \mathrm{~h}$ and then stored in PBS buffer with $0.3 \mathrm{M}$ sucrose and $0.01 \% \mathrm{NaN}_{3}$ ) and stained with mucihematein (10-15 s, Jägersten 1952) or Shirlastain $(1 \mathrm{~min})$ to increase the contrast of glandular structures. Specimens were prepared as permanent whole mounts in glycerol and thereafter examined, measured and photographed with an Olympus DP71 camera mounted on an Olympus BX50 microscope at the Marine Biological Section, University of Copenhagen (MBS, UC).

Scanning electron microscopy studies (SEM) were performed on material fixed in $2 \%$ glutaraldehyde (in $0.1 \mathrm{M}$ cacodylate buffer with $0.3 \mathrm{M}$ sucrose) for $24 \mathrm{~h}$, thereafter transferred to $0.1 \mathrm{M}$ cacodylate buffer with $0.3 \mathrm{M}$ of sucrose. Material was post-fixed for $60 \mathrm{~min}$ in $1 \%$ osmium 
tetroxide (in $0.1 \mathrm{M}$ cacodylate buffer), rinsed in distilled water, dehydrated through a graded ethanol series, transferred to $100 \%$ acetone and critical-point dried. Dried specimens were then mounted on aluminum stubs, sputter coated with platinum and examined with a JEOL JSM$6335 \mathrm{~F}$ field emission scanning electron microscope at the Natural History Museum of Denmark, University of Copenhagen.

\section{Sediment analyses}

Sediment analyses were performed from a 100-g sediment subsample (dried for $24 \mathrm{~h}$ at $60^{\circ} \mathrm{C}$ ) (Buchanan 1984), and granulometric parameters were obtained with the RYSGRAN package for R (R Development Core Team 2012), following the method of McCammon (1962). Verbal classification is based on Wentworth tables (Wentworth 1922).

\section{DNA barcoding}

Specimens for DNA barcoding were identified alive with light microscopy and preserved in ethanol, voucher specimens being type material (see description of each species for details). DNA extractions were performed from entire single specimens using a Qiagen DNeasy Tissue and Blood kit, following protocols provided by manufacturer. DNA elution was repeated twice with the same $80 \mu \mathrm{l}$ of buffer to maximize the amount of DNA yielded. A total of 659 base pairs of the mitochondrial protein-coding gene cytochrome $c$ oxidase subunit I (COI) were amplified with universal primers (Folmer et al. 1994). Polymerase chain reactions (PCRs) were performed with the Illustra PuReTaq ReadyTo-Go PCR Beads, following the manufacturer's protocol. PCRs included $2 \mu \mathrm{l}$ of template DNA and $1 \mu \mathrm{l}$ of each primer and were carried out using a Bio-Rad S1000 Thermal Cycler. PCR protocol involved a 1-min initial denaturation at $94{ }^{\circ} \mathrm{C}$, followed by 40 cycles consisting of a denaturation step $\left(94{ }^{\circ} \mathrm{C}, 30 \mathrm{~s}\right)$, annealing $\left(50{ }^{\circ} \mathrm{C}, 30 \mathrm{~s}\right)$ and extension $\left(72{ }^{\circ} \mathrm{C}, 1 \mathrm{~min}\right)$, ending with a final extension at $72{ }^{\circ} \mathrm{C}$ for $7 \mathrm{~min}$. PCR products were resolved by E-Gel $2 \%$ SYBR Safe agarose gels (Invitrogen) and purified with E.Z.N.A. Cycle-Pure kit. Purified products were sent to Macrogen Europe Laboratory for sequencing. Sequences were assembled with Sequencer 4.10.1 (Gene Codes Corporation, Ann Arbor, MI, USA). All COI barcodes were submitted to GenBank (see descriptions for GenBank accession numbers.

Additional material examined for morphological comparisons

Several species of Protodrilus were examined for comparison, including type material from $P$. adhaerens major
Fig. 2 Protodrilus corderoi $n$. sp. Light micrographs. a Lateral view of midbody segments, showing the arrangement of the epidermal glands. b Dorsal view of the head of a live adult specimen. c Dorsal view of the body cavity, segment 12 . d Epidermal glands, midbody segments. e Pores of the epidermal glands, midbody segments. f Ventral view of the palp, showing long compound cilia. $\mathbf{g}$ Segmental adhesive gland, midbody segment. h Lateral organ on segment 12, showing the gonopores. i Head, lateral view. j Lateral view of midbody segments, showing oocytes. k Oocyte segment 12 , dorsal view. ag segmental adhesive glands, $g l$ epidermal glands, go gonopore, $g p$ epidermal glands pore, $l c$ long cilia, lo lateral organ, loc lateral organ ciliation, mo mouth, om oblique muscles, oo oocytes, $p a$ palp, pe peristomium, $p h$ pharynx, $p r$ prostomium, $s g$ salivary glands, $s p$ sperm

Jouin, 1968 (MNHN POLY TYPE 1165), P. affinis Jouin in Cabioch, L'Hardy and Rullier, 1968 (MNHN POLY TYPE 1160), P. albicans Jouin, 1970 (MNHN POLY TYPE 1161), P. brevis Jouin, 1970 (MNHN POLY TYPE 1385), $P$. draco Martinez, Di Domenico, Jörger, Norenburg, Worsaae, 2013 (ZMUC-POL 0021740-02184; ZMUC-POL 002209-002211), P. gelderi Riser, 1997 (MNHN POLY TYPE 1320-1321, MUH P2352-P23533), P. gracilis von Nordheim, 1989 (MUH P-18974), P. helgolandicus von Nordheim, 1983 (MUH, P-17407), P. hochbergi Martinez, Di Domenico, Jörger, Norenburg, Worsaae, 2013 (ZMUCPOL 002186-002201; ZMUC-POL 002213-002214), P. hypoleucus tenuis Jouin in Cabioch, L'Hardy and Rullier, 1968 (MNHN POLY TYPE 1295), P. jägersteni von Nordheim, 1989 (MUH P-18978), P. similis Jouin, 1970 (MNHN POLY TYPE 1294), P. smithsoni Martinez, Di Domenico, Jörger, Norenburg, Worsaae, 2013 (ZMUC-Pol 002161-002172) and P. submersus von Nordheim, 1989 (MUH, P-18984), as well as newly collected material of $P$. cf. jägersteni von Nordheim, 1989 and P. cf. submersus von Nordheim, 1989 from Lord Howe and Kennedy Island (Australia) and Mono Island and Nusa Anghana (Solomon Islands), P. hypoleucus Armenante, 1903 and P. hypoleucus tenuis Jouin, 1970c from Roscoff (France), P. helgolandicus von Nordheim, 1983 from Tjärno (Sweden), $P$. purpureus Schneider, 1868, from Sardinia (Italy) and Tjärno (Sweden) and P. schneideri Langerhans, 1880 from Lanzarote (Canary Islands).

Museum abbreviations:

$\begin{array}{ll}\text { MNHN } & \begin{array}{l}\text { Muséum d'Histoire Naturelle-Paris } \\ \text { ZMUC }\end{array} \\ & \begin{array}{l}\text { Zoological Museum of University of } \\ \text { Copenhagen }\end{array} \\ \text { MUH } & \text { Zoologisches Museum of Hamburg }\end{array}$

\section{Results}

Family Protodrilidae Czerniavsky, 1881

Genus Protodrilus Hatschek, 1880 [von Nordheim 1989] 

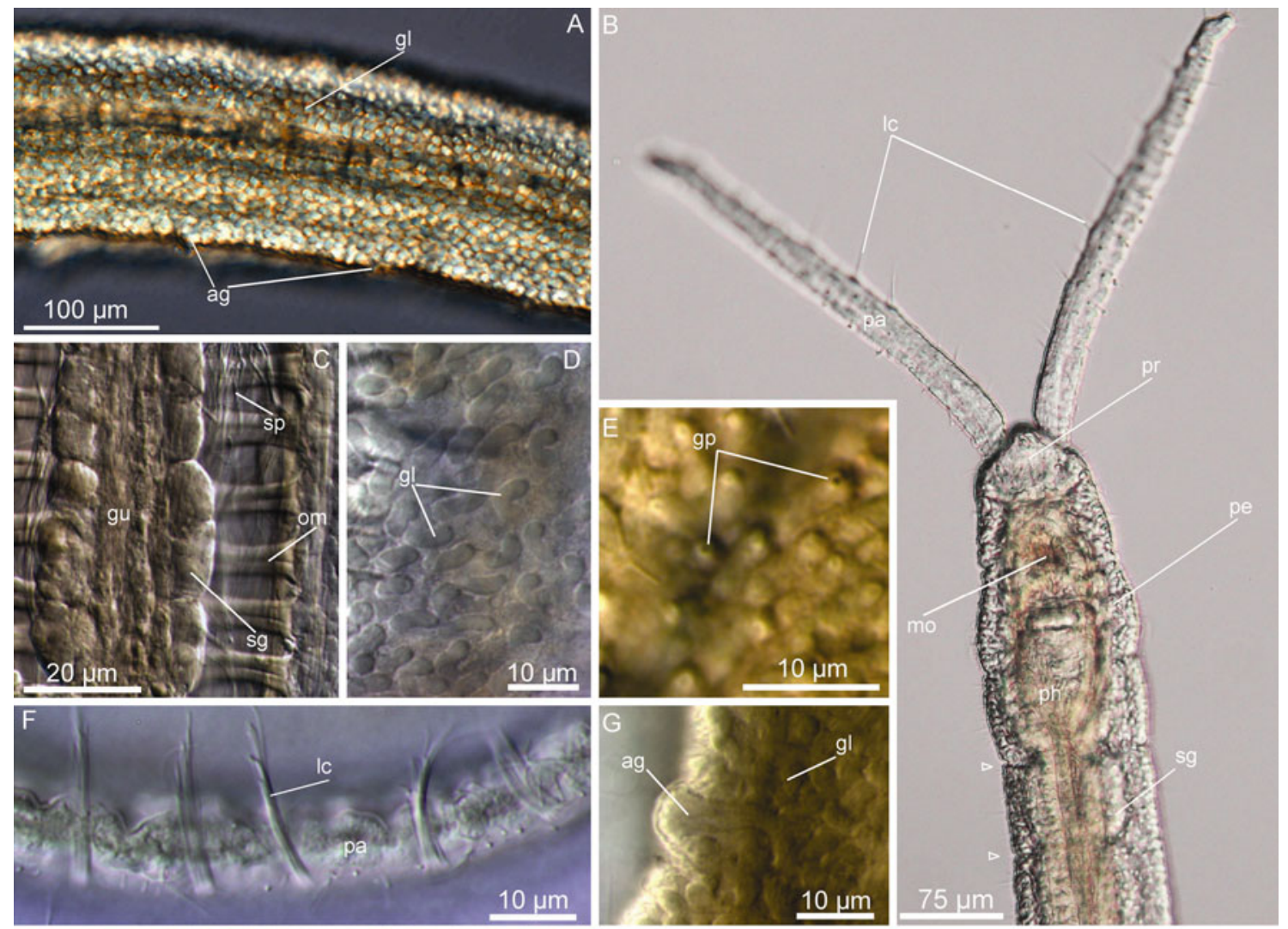

$10 \mu \mathrm{m}$
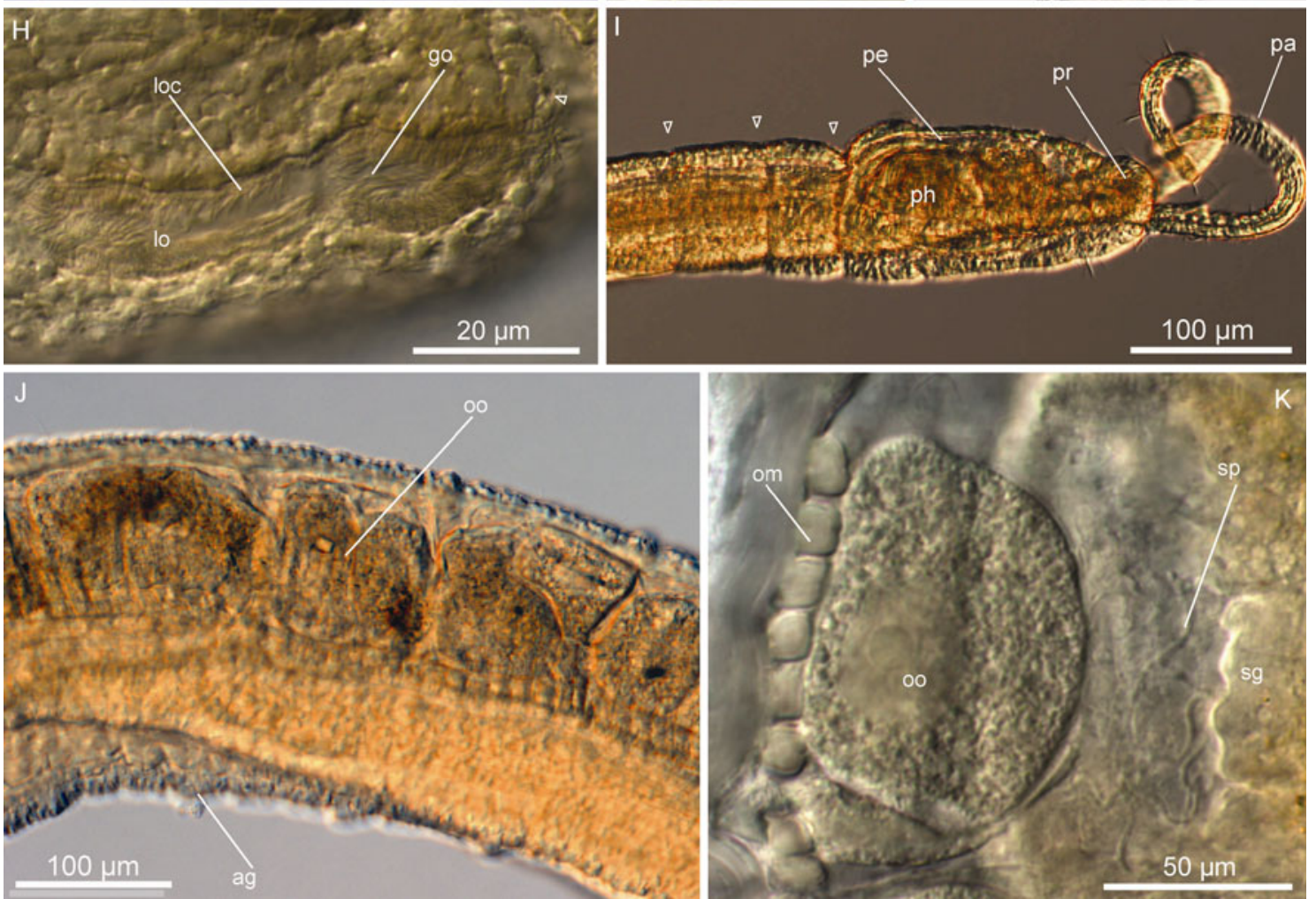

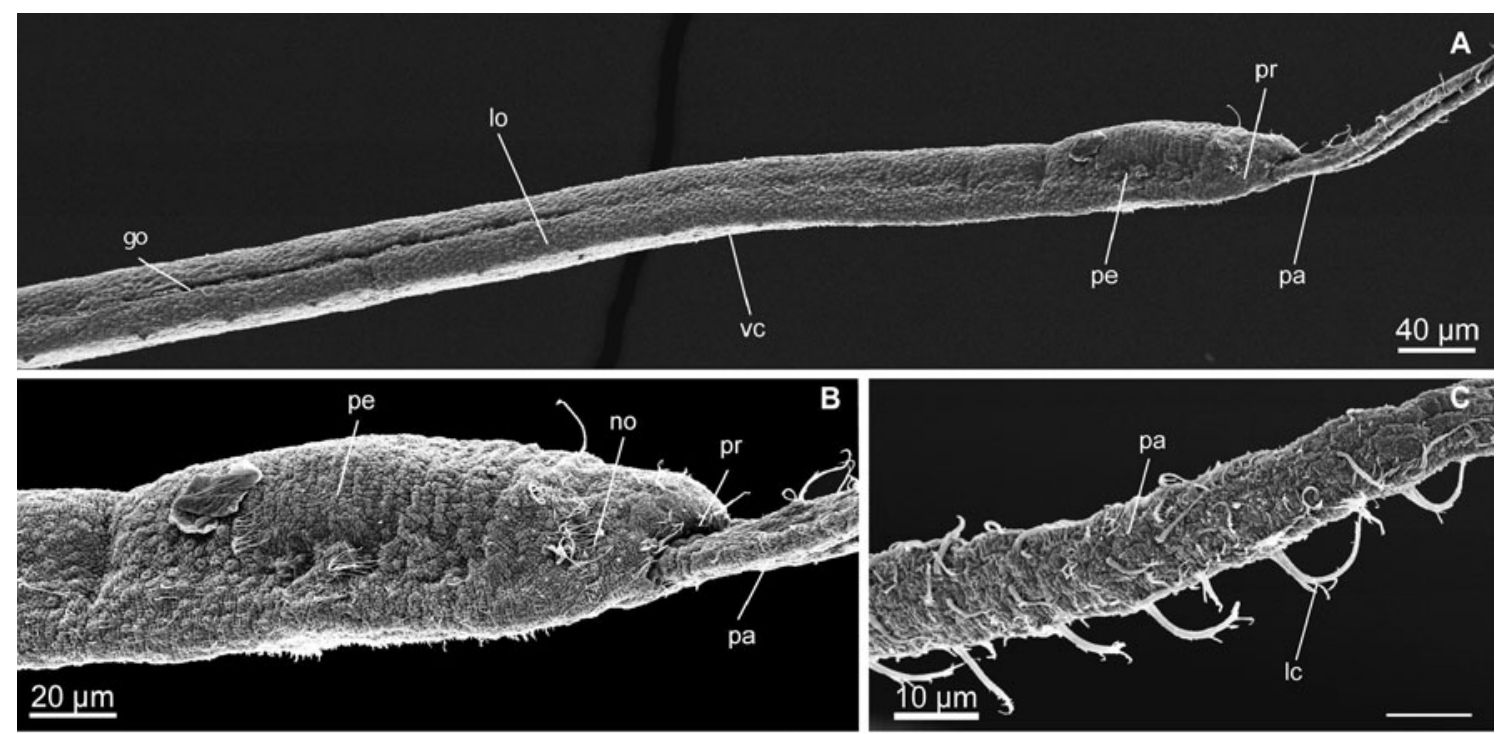

\section{$20 \mu \mathrm{m}$}
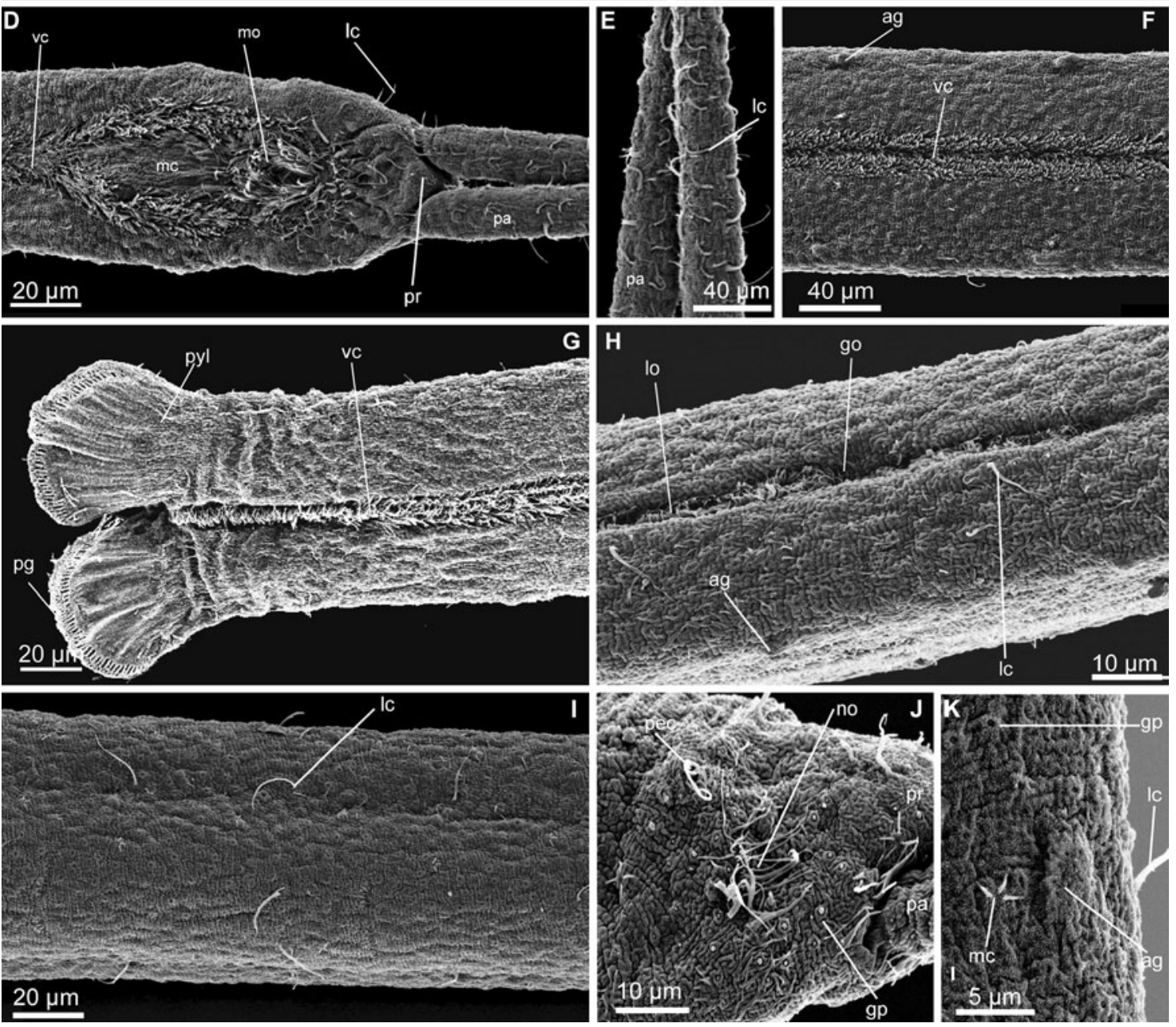

Fig. 3 Protodrilus corderoi n. sp. Scanning electron micrographs. a Anterior end of a male, showing the arrangement of the lateral organs. Arrow head pointing at the septa. b Head, lateral view, arrow head pointing at the septa. c Palp, lateral view. d Head, ventral view. e Palps, ventral view. f Midbody segments, ventral view. g Pygidium, ventral view. h Lateral organs on segments 11-12. i Midbody

segments, lateral view. j Nuchal organ. $\mathbf{k}$ Segmental adhesive gland on a midbody segment. go gonopores, $g p$ glandular pores, $l c$ long cilia, lo lateral organ, mo mouth, $m c$ multiciliated cells, no nuchal organ, $p a$ palp, $p c$ peristomial ciliation, $p e$ peristomium, $p r$ prostomium, $p y l$ pygidial lobes, $a g$ adhesive glands, $v c$ ventral ciliation 
Table 1 Meristic and morphometric characters of neotype and whole mounted additional material of $P$. corderoi, and holotype and whole mounted paratype material P. ovarium and P. pythonius, as well as measures on P. corderoi from du Bois-Reymond Marcus (1948)

\begin{tabular}{|c|c|c|c|c|c|c|c|c|c|c|c|c|c|c|c|c|}
\hline & \multicolumn{6}{|c|}{ P. corderoi } & \multicolumn{5}{|c|}{ P. ovarium } & \multicolumn{5}{|c|}{ P. pythonius } \\
\hline & Marcus $^{\mathrm{a}}$ & Neotype & Mean & $\operatorname{Max}$ & Min & $N$ & Holotype & Mean & Min & $\operatorname{Max}$ & $N$ & Holotype & Mean & Min & $\operatorname{Max}$ & \\
\hline Total L. & 2,500 & 2,700 & 2,988 & 3,541 & 2,500 & 5 & 5,595 & 5,243 & 4,529 & 5,948 & 11 & 3,400 & 3,200 & 2,900 & 3,500 & 3 \\
\hline Max. W. & $60-100$ & 97 & 82 & 101 & 53 & 7 & 77 & 79 & 67 & 95 & 11 & 163 & 140 & 120 & 165 & 3 \\
\hline L. prostomium & - & 31 & 22 & 31 & 15 & 7 & 20 & 22 & 16 & 32 & 11 & 40 & 35 & 30 & 40 & 3 \\
\hline W. prostomium & - & 39 & 37 & 42 & 29 & 5 & 51 & 44 & 36 & 52 & 11 & 40 & 40 & 30 & 40 & 3 \\
\hline L. peristomium & - & 130 & 122 & 154 & 73 & 7 & 171 & 167 & 143 & 179 & 11 & 250 & 240 & 198 & 286 & 3 \\
\hline W. peristomium & - & 95 & 79 & 104 & 48 & 7 & 83 & 87 & 69 & 110 & 11 & 180 & 177 & 147 & 235 & \\
\hline Palp L. & $180-250$ & 250 & 195 & 250 & 162 & 7 & 262 & 247 & 195 & 279 & 10 & 450 & 480 & 450 & 525 & 2 \\
\hline L. pygidium & $25-40$ & 45 & 37 & 45 & 25 & 4 & 43 & 39 & 25 & 50 & 9 & 70 & 60 & 40 & 70 & 2 \\
\hline W. pygidium & - & 55 & 38 & 55 & 27 & 5 & 50 & 46 & 39 & 52 & 9 & 25 & 22 & 20 & 25 & 3 \\
\hline N. segments & $20-40$ & 47 & 41 & 47 & 39 & 7 & 58 & 53 & 41 & 63 & 10 & 25 & 28 & 25 & 30 & 3 \\
\hline
\end{tabular}

$L$ Length, Max maximum, Min minimum, $N$ number of specimens, $W$ width

a du Bois-Reymond Marcus (1948)

Protodrilus corderoi du Bois-Reymond Marcus 1948 Emended

(Figs. 2, 3; Table 1)

\section{References}

(du Bois-Reymond Marcus 1948; Kirsteuer 1967; Di Domenico et al. 2009)

\section{Neotype}

Female, $2.7 \mathrm{~mm}$ long (whole mount ZMUC-Pol 3238), Praia do Toque-Toque, São Sebastião, São Paulo $\left(23^{\circ} 51^{\prime} 04^{\prime \prime} \mathrm{S} 45^{\circ} 29^{\prime} 27^{\prime \prime} \mathrm{W}\right)$. Reflective beach, medium sand $(\Phi=1.6-2.1)$ moderately well sorted $(\Phi=0.6-0.8)$, $0-1 \mathrm{~m}$ depth. Justifications for designation of new type are provided below. Date: April 17,2011, Col: M. Di Domenico.

\section{Additional material}

One whole mounts (ZMUC-Pol 3239), same locality as neotype. Two SEM specimens (ZMUC-Pol, 3246-3247) and six whole mounts (ZMUC-Pol, 3240-3245), Praia da Peninsula, Barra Velha, Santa Catarina, Brazil $\left(26^{\circ} 38^{\prime} 09^{\prime \prime} \mathrm{S}\right.$ $\left.48^{\circ} 41^{\prime} 04^{\prime \prime} \mathrm{W}\right)$. Swash zone, medium-coarse sand $(\Phi=0.9-1.16)$, moderately well sorted $(\Phi=0.5-0.56)$, intertidal. Praia do Tombo, Guarujá, São Paulo, medium sand $(\Phi=1.0-1.5)$ well sorted $(\Phi=0.37-0.49)$, intertidal in an intermediate beach $\left(24^{\circ} 00^{\prime} 52^{\prime \prime} \mathrm{S} 46^{\circ} 16^{\prime} 23^{\prime \prime} \mathrm{W}\right)$. A vial containing several specimens preserved in ethanol (ZMUCPol 3248), from the same locality as the holotype; DNA barcoding (GenBank Acc. KC763839). Several days in 2010 to 2011, Col: M. Di Domenico.

Diagnosis

Hyaline body, with 39-47 segments. All segments with well-developed septa. Salivary glands in segments 1 to 8-16. External ciliation consisting of one ciliary ring on the peristomium (dorsally incomplete) and scarce multiciliated cells on the palps and trunk. Trunk epidermis characterized by high abundance of vacuolar rounded glands. Segmental adhesive glands in all segments. Males with continuous lateral organs on segments 7-12. Sperm in body cavity from segment 9 to pygidium. Four pairs of spermioducts with gonopores on segments 9-12. Females with large oocytes from segment 15 .

\section{Description emended}

(Measurements provided from neotype; ranges of all additional material in parentheses; measures given in Table 1). Body slender and hyaline, $2.7 \mathrm{~mm}$ long (2.5-3.5 mm, $n=5, \mathrm{LM})$ and maximum $100 \mu \mathrm{m}$ wide (55-100 $\mu \mathrm{m}, n=7, \mathrm{LM})$, body with epidermical rounded glands (Fig. 2a) and 47 segments (39-47, $n=7$, LM), all with well-developed septa, although not clearly visible externally (Figs. 2a, b, 3a). Prostomium rounded, $30 \mu \mathrm{m}$ long (15-30 $\mu \mathrm{m}, n=6$, LM) and $40 \mu \mathrm{m}$ wide $(30-40 \mu \mathrm{m}$, $n=10$, LM), with two filiform palps, $250 \mu \mathrm{m}$ long (160-250 $\mu \mathrm{m}, n=7$, LM), bearing long cilia (Figs. 2f, 3c, d, e). Nuchal organs indistinct and relatively small (ca. $10 \mu \mathrm{m}$ diameters), dorsal and poorly ciliated (Fig. 3b, j). Salivary glands in segments $1-16$ (up to segment 20 in 
paratypes) (Fig. 2b, c), as clusters of few big cells, ventrally along the esophagus wall.

Epidermis characterized by the presence of abundant vacuolar rounded glands, ca. $5 \mu \mathrm{m}$ diameter, (Fig. 2a, d). Glands open as small circular pores (Figs. 2e, 3j) giving the animal a very distinctive epidermal texture visible with SEM (Fig. 3i-k). Paired segmental adhesive glands ventrally on each segment, positioned lateral to the midventral ciliary glands lining the midventral ciliary band. They consist of an elevation of the with ca. 10 small terminal pores (Figs. 2g, 3f). Pygidium with paired rounded lobes, $45 \mu \mathrm{m}$ long $(25-45 \mu \mathrm{m}, n=4, \mathrm{LM})$ and $55 \mu \mathrm{m}$ wide (30-55 $\mu \mathrm{m}, n=4$, LM), with ca. 50 distal adhesive glands openings (Fig. 3g).

Ciliation consisting of scattered multiciliated cells on the palps, head and trunk (presumably corresponding to multiciliary sensory cells type I, after Purschke 1993, or multiciliated cells type Ia in Martínez et al. 2013). Each multiciliated cell contains stiff long cilia (length of cilia: 15-20 $\mu \mathrm{m}, n=2$, LM, lc, Figs. 2f, 3c, e), which on live animals is discernible as one group of stiff cilia that on SEM specimens can be further resolved to include ca. 5 long cilia. Multiciliated cells are organized in 2-3 apical groups and one short ventral band on the prostomium, and as a single short bandlet on the peristomium, extending transversally from the nuchal organs to the ventral side of the body (Fig. 3k). Trunk with few (ca. 5-10) multiciliated receptors per segment, aligned as weak lateral bands from the midbody to the pygidium (length cilia: $15-18 \mu \mathrm{m}$, $n=2$, LM) (Fig. 3f, i). Absence of pigmented eyespots and so-called statocysts. Midventral ciliary bands from peristomium to pygidium, surrounding the mouth as a double ring of ciliation (Fig. 3e).

Males with paired lateral organs on segments $7-12$, as continuous ciliated bands surrounded by glands (Fig. 3a). Four pairs of spermioducts in segments $8-11$, with gonopores opening in the lateral organs in the following segments 9-12 (Figs. 2h, 3h, 7). Sperm present from segment 9, occupying the entire body cavity. Mature females with 2-5 oocytes per segment (30-35 $\mu$ m diameter, $n=2)$ from segment 15 (Fig. 2j, k).

\section{Molecular data}

659 base pairs of the cytochrome $c$ oxidase subunit I were amplified (GenBank Acc. KC763839), coding for 220 amino acids with a guanine-cytosine content of $45.4 \%$.

Habitat

Protodrilus corderoi was collected in the swash zone at the intermediate-reflective beaches of Toque-Toque, Tombo and Peninsula, always in medium to coarse well-sorted sand at $0-1 \mathrm{~m}$ depth. All these beaches are sheltered from southeast swells by natural/artificial barriers.

\section{Remarks}

du Bois-Reymond Marcus described most of the important diagnostic features for P. corderoi, all of them confirmed by our own observations. We provide herein novel information on male and female reproductive features (mature females with 2-5 oocytes per segment from segment 15 , males with continuous lateral organs on segments 7-12), paired ventral segmental adhesive glands, presence of scattered multiciliated cells on the palps, head and trunk and arrangement of epidermal glands, with numerous small rounded vacuolar glands covering the whole epidermis. Further ecological information is also provided, from collections in medium to coarse well-sorted sand at $0-1 \mathrm{~m}$ depth in the swash zone of intermediate-reflective beaches. du Bois-Reymond Marcus (1948) collected P. corderoi in coarse to very coarse sand $(0.2-2 \mathrm{~mm})$ near the upper tidemark, a few centimeters beneath the surface at sandy beaches in São Sebastiã Island. New type material is here designated (see below).

$P$. corderoi resembles $P$. adhaerens Jägersten, 1952 (Jägersten 1952), P. gracilis von Nordheim, 1989, P. jouini von Nordheim, 1989 and P. similis Jouin, 1970, in the presence of segmental adhesive glands. It differs from them in the presence of continuous lateral organs on segments 7-12 (separated and on segm 6-12 in P. adhaerens, segm 7-13 in $P$. gracilis, segm. $9-13$ in $P$. jouini and segm. 6-11 in $P$. similis) and four pairs of spermioducts (two in $P$. gracilis and $P$. adhaerens and five in $P$. similis). With its abundant small rounded glands, it differs further in the structure of the epidermis from $P$. adhaerens, $P$. gracilis and $P$. jouini with abundant spindle-shaped bacillary glands and position of the salivary glands (only extending to segments 5-6 in P. adhaerens, $P$. gracilis and $P$. jouini). Protodrilus corderoi also resembles $P$. helgolandicus (Nordheim 1983) and P. hypoleucus (Armenante 1903) in the presence of abundant epidermal glands and continuous lateral organs with four spermioducts, but differing in the presence of segmental adhesive glands and the position of the lateral organs (segm. 7-12 in P. corderoi versus segm. 5-8 in P. hypoleucus and segm. 6-9 in P. helgolandicus).

Justification for the neotype

The original material of $P$. corderoi of Eveline Du BoisReymond Marcus from São Sebastião Island no longer exists, and it is necessary to define this species (Article 75, ICZN). Indeed, she did not state any type material or collections reference numbers in her papers. Some material may remain at the Zoological Museum of São Paulo (MZUSP) 
and Zoological Museum of Natural History of Montevideo, but since serial numbers were not provided, the collections related to the original material cannot be searched with precision. Furthermore, other Protodrilus collections from different authors at the same localities are not available. Confusion over the identity of this species has precluded description of sibling species (Kirsteuer 1967).

Accordingly, a neotype from Toque-Toque, close to the place where Eveline du Bois-Reymond Marcus made her collecting in 1948, is herein designated. The collecting has been done from the vicinity of permanent research facilities, favoring future collecting of fresh material for further research on life history and genetics. A redescription will serve as a baseline from which the sibling species of $P$. corderoi can be formally described and contrasted with the type species.

\section{Protodrilus ovarium n. sp.}

(Figs. 4, 5; Table 1)

(Di Domenico et al. 2009)
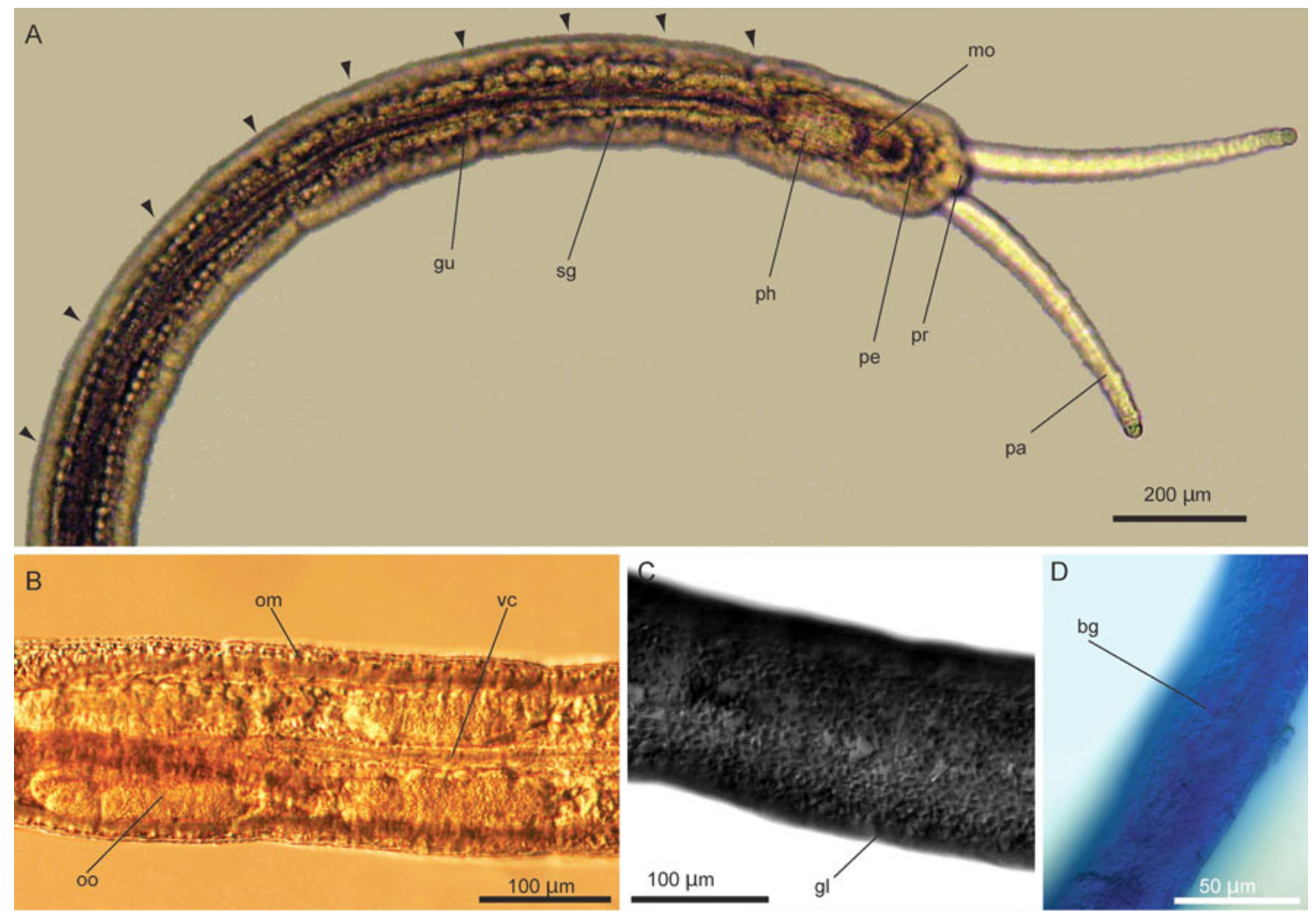
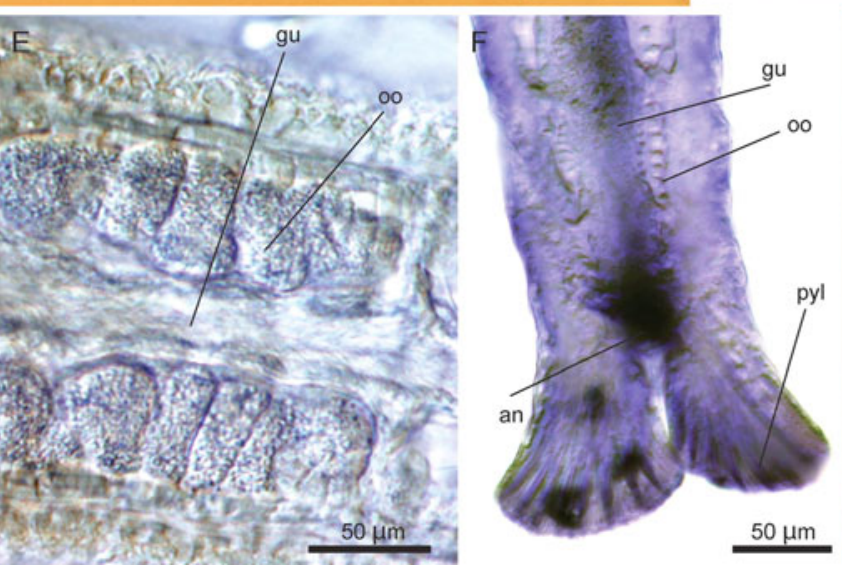

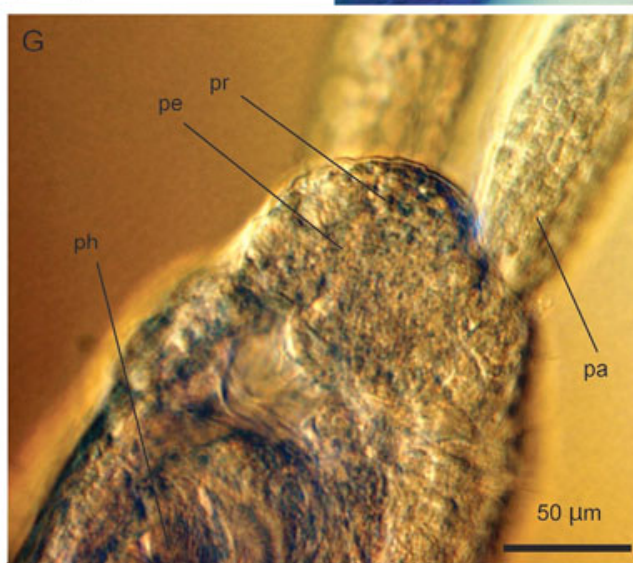

Fig. 4 Protodrilus ovarium n. sp. Light micrographs. a Anterior view. b Midbody view, showing female oocytes. c, d Two micrograph showing the epidermal glands, e view of segment 20 of a female showing oocytes packets within bilateral and gut, $\mathbf{f}$ posterior view of a female showing oocytes in the bilateral packages and pygidium, g anterior view of prostomium, showing palps insertion. Triangles indicate septa of the segments. $a n$ anus, $b g$ bacillary glands, $g l$ epidermal glands, $g u$ gut, om oblique muscles, oo oocyte, pa palp, pe peristomium, $p h$ pharyngeal bulb, $p r$ prostomium, $p y l$ pygidial lobes, $s g$ salivary glands, $v c$ ventral ciliation 

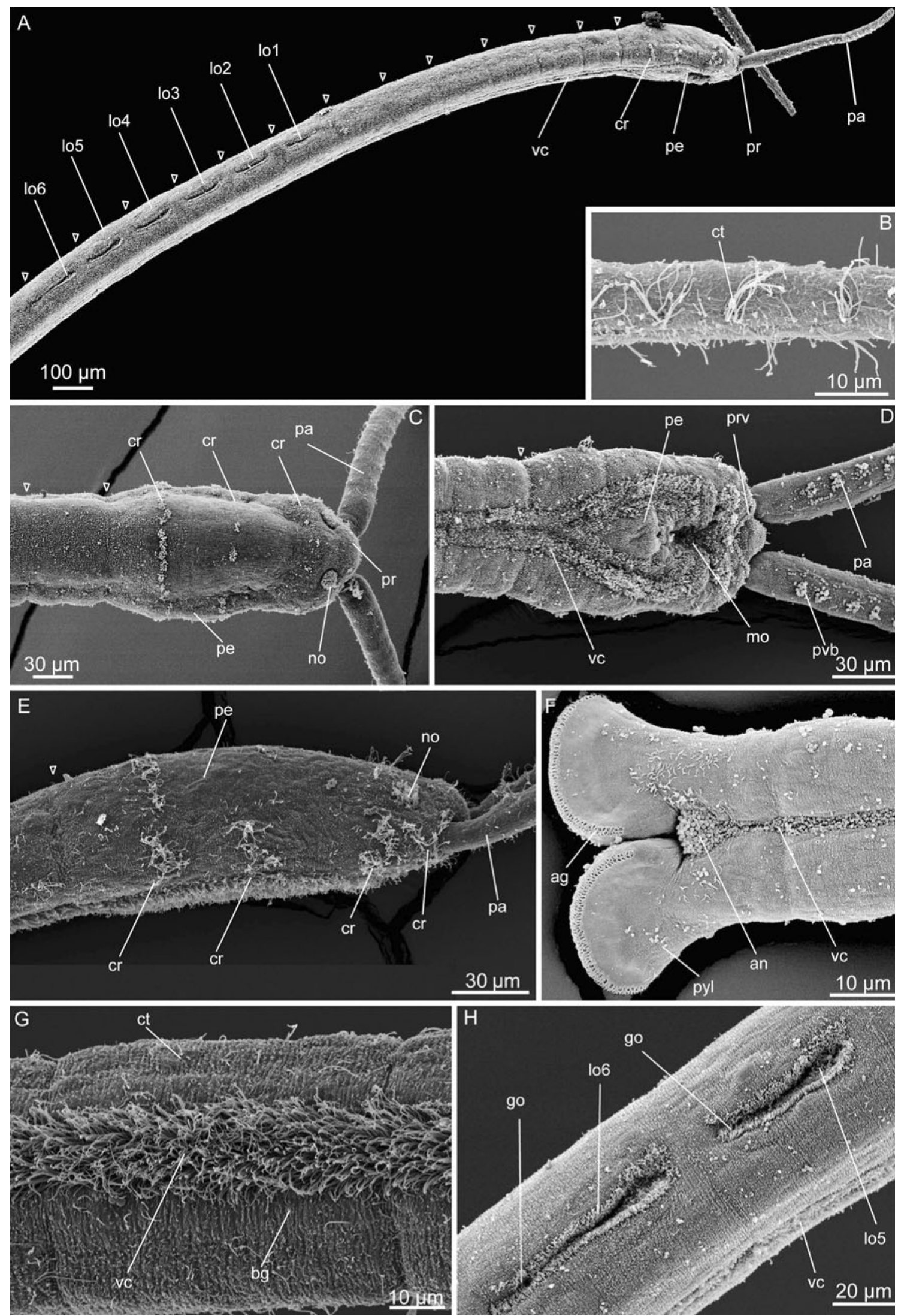
\Fig. 5 Protodrilus ovarium n. sp. Scanning electron micrographs. a Lateral view of a male showing peristomium, ciliary ring, ventral ciliation and segmented lateral organs. b Lateral view of palps, showing arrangement of tufts of cilia. c Dorsal view, anterior palps and position of the nuchal organs. d Ventral view of anterior end. e Lateral view of anterior end. $f$ Ventral view of posterior end. g Ventral view of middle body. $\mathbf{h}$ Lateral view of the segment 11-12 showing the fifth and sixth lateral organs of a male and gonopores. $\mathrm{cr}$ ciliary ring, ct ciliary tufts, $b g$ bacillary glands, go gonopores, lo lateral organ, lo1 first lateral organ, lo2, lo3, lo4, lo5, lo6 lateral organ 2, 3, 5 and 6, mo mouth, no nuchal organ, pa palp, pe peristomium, $p r$ prostomium, prv ventral prostomium, $p y l$ pygidial lobes, $v c$ ventral ciliation

\section{Holotype}

Male, $5.6 \mathrm{~mm}$ long (ZMUC-Pol 3249). Praia de Estaleiro, Santa Catarina, Brazil $\left(27^{\circ} 01^{\prime} 49^{\prime \prime} \mathrm{S} 48^{\circ} 34^{\prime} 48^{\prime \prime} \mathrm{W}\right)$, shoaling zone, medium to coarse $(\Phi=0.34-1.14)$ moderately to well-sorted $(\Phi=0.4-1.0)$ sand, $3 \mathrm{~m}$ depth. Date: November 09, 2010, Col: M. Di Domenico and A. P. Cattani.

\section{Paratypes}

Twenty-four whole mounts (ZMUC-Pol, 3250-3273) and four SEM specimens (ZMUC-Pol, 3274-3277), same locality as holotype. Eight whole mounts (ZMUC-Pol, 3278-3285), Praia de Estaleirinho, Santa Catarina, Brazil $\left(27^{\circ} 02^{\prime} 59^{\prime \prime} \mathrm{S} 48^{\circ} 35^{\prime} 12^{\prime \prime} \mathrm{W}\right)$, shoaling zone, medium to coarse $(\Phi=0.34-1.14)$ moderately to well-sorted $(\Phi=0.4-1.0) ; 3$ m depth. Date: November 09, 2010, Col: M. Di Domenico and A. Cattani. A vial containing several specimens, identified alive, preserved in ethanol (ZMUCPol, 3288) and one SEM specimens (ZMUC-Pol, 3286), Barra da Tijuca, Río de Janeiro, Brazil $\left(23^{\circ} 00^{\prime} 51^{\prime \prime} \mathrm{S}\right.$ $\left.43^{\circ} 22^{\prime} 23^{\prime \prime} \mathrm{W}\right)$, swash zone, medium sand $(\Phi=0.9-1.6)$ and moderately well-sorted sand $(\Phi=0.5-0.6)$, intertidal. Date: August 05, 2011, Col: M. Di Domenico and R. Barroso. A vial containing several specimens preserved in ethanol (ZMUC-Pol 3287), same locality as holotype; DNA barcoding (GenBank Acc KC763838).

\section{Diagnosis}

Hyaline body, with 41-63 segments. Salivary glands in segments 1-9. External ciliation consisting of three ciliary rings on peristomium (anterior ring, dorsally incomplete); no ciliary rings on trunk and very scarce cilia. Males with segmented lateral organs on segments 7-12. Sperm from segment 6-7. Three pairs of spermioducts with gonopores on segments 10-12. Females with oocytes from segment 12 , arranged in paired segmental ovaries lateral to the gut.
Etymology

From Latin, "ovarium" (ovary), as a reference to the characteristic arrangement of the oocytes, in paired segmental ovaries lateral to the gut.

\section{Description}

(Measurements provided from holotype; ranges of all adult types in parenthesis; measures given in Table 1). Body hyaline, $5.6 \mathrm{~mm}$ long $(4.5-5.6 \mathrm{~mm}, n=11)$ and maximum $80 \mu \mathrm{m}$ wide (70-95 $\mu \mathrm{m}, n=11$, LM), with 58 segments (41-63, $n=10$ ), all with well-developed septa (Fig. 4a). Prostomium rounded, $20 \mu \mathrm{m}$ long $(15-30 \mu \mathrm{m}, n=11$, $\mathrm{LM})$ and $50 \mu \mathrm{m}$ wide $(35-50 \mu \mathrm{m}, n=11)$, with two filiform motile palps, $260 \mu \mathrm{m}$ long $(195-280 \mu \mathrm{m}, n=10)$ bearing a ventral band of ciliary tufts (Fig. 5b, d). Nuchal organs rounded and dorsal, 10-15 $\mu \mathrm{m}$ diameter and densely ciliated (Fig. 5c). Salivary glands in segments $1-9$ as clusters of squared and rounded cells, on both sides of the gut.

Epidermis with abundant scattered rounded vacuolar glands, ca. $5 \mu \mathrm{m}$ diameter, scattered on the body surface (Fig. 4c); ca. 5-10 bacillary glands per segment, more abundant around midventral ciliary band (Fig. 4d). Bacillary glands open as small pores slightly raised above the cuticle (Fig. 5g). Pygidium with two paddle-shaped lobes, $45 \mu \mathrm{m}$ long $(25-50 \mu \mathrm{m}, n=9)$ and $45 \mu \mathrm{m}$ of maximum width (40-50 $\mu \mathrm{m}, n=9)$, each with ca. 50 distal adhesive gland openings, arranged in two rows (Figs. 4h, 5f).

Prostomium with 2-3 tufts of motile cilia around the insertion of the palps (Fig. 5c, d), and a ventral transverse band between prostomium and peristomium (Fig. 5e). Palps with ventral band of ciliary tufts (Fig. 5d) and scattered short individual cilia. Peristomium ciliation with three rings of motile cilia (Fig. 5e). First and second ciliary ring less developed and dorsally incomplete; consisting of 3-4 tufts of 10-15 cilia at each side of the peristomium spaced ca. $5 \mu \mathrm{m}$ apart (Length of cilia: $10-15 \mu \mathrm{m}, n=3$, SEM); at 30-40 $\mu \mathrm{m}$ and $80-100 \mu \mathrm{m}$ from anterior margin of prostomium $(n=3, \mathrm{SEM})$. Third ring similar to the anterior ones but more dense, $120-150 \mu \mathrm{m}$ from the anterior end ( $n=3$, SEM; Length cilia: $10-15 \mu \mathrm{m}, n=3$, SEM).

Absence of pigmented eyespots and so-called statocysts. Trunk without ciliary rings and only few groups of ca. 7-10 short cilia (Length of cilia: ca. $10 \mu \mathrm{m}, n=2$, SEM) arranged in a circle projected in different directions (multiciliated cells type II, sensu Purshke 1993) (Fig. 5g). Midventral ciliary band as two bands of multiciliated cells, with double ring around mouth, and a dense ciliary area around the anus (Fig. 5d). 
Males with paired separated lateral organs from segment $7-12$, ciliated and surrounded by glands. Three pairs of spermioducts in segments 9-11, openings at lateral organs on segments 10-12 (Figs. 5a, h, 7). Sperm from segment 7, filling body cavity. Females with 7-8 oocytes per segment, packed in ovaries on both sides of the gut (Fig. 4b, g), from segment 12.

\section{Molecular data}

659 base pairs of the cytochrome $c$ oxidase subunit I were amplified (GenBank Acc. KC763838), coding for 220 amino acids with a guanine-cytosine content of $43.4 \%$.

\section{Habitats}

Protodrilus ovarium n. sp. was collected at reflective beaches of Estaleiro, Estaleirinho and Barra da Tijuca beaches, in medium to coarse well-sorted sand, 0-1 m depth in swash and shoaling zones. These beaches are exposed to southwest swells.

\section{Remarks}

Protodrilus ovarium n. sp. differs from P. corderoi in the absence of adhesive segmental glands, separated lateral organs (continuous in $P$. corderoi) with three spermioducts (versus four in $P$. corderoi), salivary glands to segment 9 (segments 8-20 in $P$. corderoi), three ciliary rings on the peristomium (versus one in $P$. corderoi) and different glands in the epidermis (rounded glands bigger in $P$. corderoi, covering the entire body).

Protodrilus ovarium resembles $P$. similis, $P$. hypoleucus, $P$. draco, $P$. helgolandicus and $P$. pierantoni in slender and translucent body, with no eyes, dorsal rounded nuchal organs, presence of peristomial ciliary rings. It differs from $P$. similis in the longer body, absence of adhesive segmental glands and presence of three spermioducts (five in $P$. similis). P. ovarium differs from P. draco, P. hypoleucus, $P$. helgolandicus and $P$. pierantoni in having separated lateral organs on segments 7-12 (versus continuous and on segments 5-8; 5-8; 6-9 and 8-13 in those species), having salivary glands in segments 1-9 (versus 14-20 in $P$. draco, $P$. hypoleucus, $P$. helgolandicus and $P$. pierantoni), and absence of unpigmented ciliary receptors, statocysts and pigmented eyes.

\section{Protodrilus pythonius n. sp.}

(Fig. 6; Table 1)

\section{Holotype}

Male, $3.5 \mathrm{~mm}$ long (ZMUC-Pol 3289). Praia da Feiticeira, Ilha Bela, São Paulo, Brazil (23⒌ $\left.50^{\prime} 43^{\prime \prime} \mathrm{S} 45^{\circ} 24^{\prime} 32^{\prime \prime} \mathrm{W}\right)$, in very coarse ( $\Phi=0.3-0.5)$ well-sorted $(\Phi=0.2-0.4)$ sand at 0-1 m depth in swash zones. Date: June 29, 2010, Col: M. Di Domenico.

\section{Paratypes}

Two whole mounts (ZMUC-Pol, 3290-3291) and two SEM specimens (ZMUC-Pol, 3292-3293), same locality and date as holotype. A vial containing some specimens preserved in ethanol (ZMUC-Pol 3294), same locality as holotype; DNA barcoding (GenBank Acc KC763840).

\section{Diagnosis}

Hyaline body, with 25-30 segments. Salivary glands in segments 1-12. External ciliation consisting of two ciliary rings on the peristomium, no ciliary rings on trunk and abundant multiciliated cells and bacillary glands on trunk. Segmented lateral organs on segments 7-16 of males; first separated and rounded. Sperm in body cavity from segment 10-12. Four pairs of spermioducts with gonopores on segments 13-16. Females with large oocytes from segment 20.

\section{Etymology}

From the Latin "pythonissa" (witch), as a reference to the beach name Feiticeira (Witch beach) where these specimens were collected. Pythonius is the male derivation of the latin word pythonissa.

\section{Description}

Measurements provided from holotype; ranges of all adult types in parentheses; measures given in Table 1. Hyaline body, $3.4 \mathrm{~mm}$ long (2.9-3.5 $\mathrm{mm}, n=3$ ) and maximum width $163 \mu \mathrm{m}(120-165 \mu \mathrm{m}, n=3$, LM) tapering segments toward the pygidium to a minimum width of $60 \mu \mathrm{m}$ in the last segment (55-60 $\mu \mathrm{m}, n=3)$; with 25-30 segments, all with well-developed septa. Prostomium rounded, $40 \mu \mathrm{m}$ long (30-40 $\mu \mathrm{m}, n=3, \mathrm{LM})$ and $40 \mu \mathrm{m}$ wide (ca. $40 \mu \mathrm{m}, n=3$ ) (Fig. 6c, d), with two filiform motile palps, $450 \mu \mathrm{m}$ long (450-525 $\mu \mathrm{m}, n=2$, LM). Conspicuous unpigmented ciliary receptors dorso-anteriorly in the prostomium (up to $15 \mu \mathrm{m}$ diameter, $n=3$ ) (Fig. 6c). Nuchal organs ca. $20 \mu \mathrm{m}$ wide, densely ciliated, oval and extending dorso-laterally (Fig. 6c). Salivary glands well developed in segments 1 to $10-11$, expanding only ventrally in segments 14-15 (Fig. 6d, f). Bacillary glands on trunk (bg, Fig. 6a), most evident in live specimens. Pygidium with two pointed lobes, $70 \mu \mathrm{m}$ long (Length: 40-70 $\mu \mathrm{m}, n=3$, LM) and maximum $25 \mu \mathrm{m}$ wide (20-25 $\mu \mathrm{m}, n=3)$, with adhesive glands (Fig. 6b). 

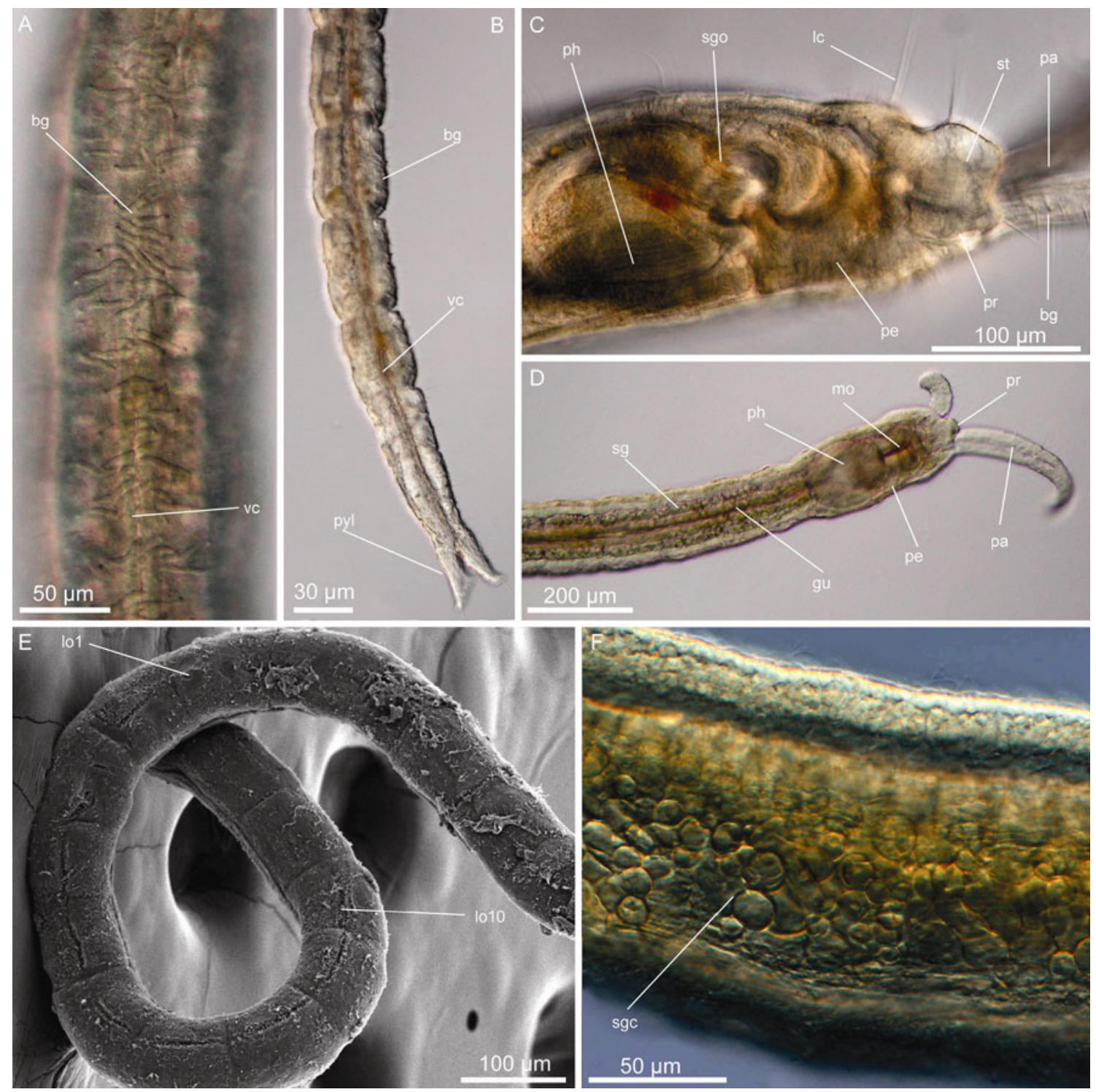

Fig. 6 Protodrilus phytonius n. sp. Light micrographs and scanning electron micrographs. a Ventral view of middle body showing bacillary glands. b Posterior view. c Lateral view of an adult indicating palp and statocyst. d Anterior end. e Lateral view of a male, first lateral organ (lol) and tenth (lolo). f Lateral view of a segment indicating a cell of the salivary glands. a-d Individuals

External ciliation comprising two ciliary rings on peristomium ( $n=1$, SEM); no ciliary rings on trunk, and abundant ciliary tufts on trunk and palps. Midventral ciliary band from peristomium to pygidium as two bands of multiciliated cells (Fig. 6b), with double ring around mouth.

Males with segmented lateral organs on segments 7-16 (Figs. 6e, 7); first consisting of a rounded ciliated pit. Sperm from segments $10-12(n=2)$. Oocytes started on segment 20 in the only studied female, however, only few oocytes were found, most likely others eggs had been spawned. photographed alive with optical microscope, e SEM and $\mathbf{f}$ individuals set photographed with an optical microscope. $g u$ gut, $l c$ long cilia, lol first lateral organ, lo10 lateral organ 10, mo mouth, no nuchal organ, pa palp, pe peristomium, $p r$ prostomium, $p h$ pharyngeal bulb, $p y l$ pygidial lobes, $s g c$ cell of the salivary glands, $s g$ salivary glands, $s g o$ salivary gland open, st statocyst, $v c$ ventral ciliation

\section{Molecular data}

659 base pairs of the cytochrome $c$ oxidase subunit I were amplified (GenBank Acc. KC763840), coding for 220 amino acids with a guanine-cytosine content of $45.1 \%$.

\section{Remarks}

Protodrilus pythonius n. sp. resembles $P$. jägersteni, $P$. submersus and $P$. smithsoni in the morphology of the nuchal organs, and palps and in the arrangement of the salivary glands and lateral organs, with the first, reduced 
Protodrilus corderoi du Bois-Reymond Marcus, 1948

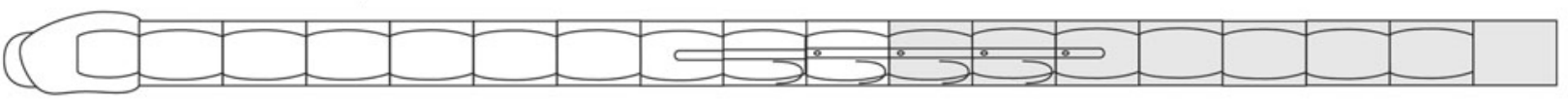

Protodrilus ovarium n. sp.

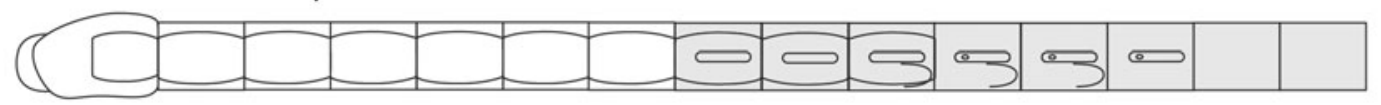

Protodrilus pythonius n. sp.

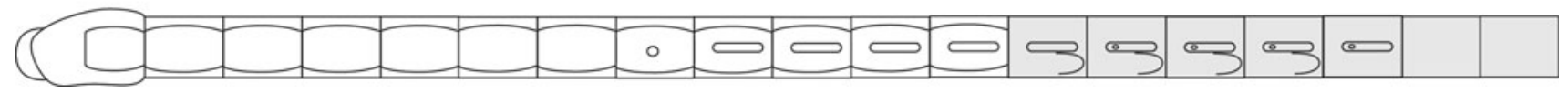

Fig. 7 Diagram of sexual characteristics (lateral organs and spermioducts of males), extension of salivary glands and fertile region of the body of $P$. corderoi, $P$. ovarium, $P$. pythonius. Spermioducts showed in the left side of the body. Fertile region hatch

lateral organ on segment 7. It differs from these in the presence of separated lateral organs, smaller body length and width, longer pygidial lobes and more tapering body. Salivary glands of $P$. pythonius are denser, consisting of big conspicuous cells.

Habitats

Protodrilus pythonius n. sp. was exclusively collected at Feiticeira beach, in very coarse well-sorted sand at 0-1 m depth in swash zone. Feiticeira beach presents a reflective state and is sheltered from predominant NE-SW waves system by the presence of São Sebastião Island.

\section{Discussion}

Sixty years after the original description of $P$. corderoi du Bois-Reymond, 1948, this is the first taxonomic paper on Protodrilus from Brazil. The two new species herein described, together with the five species recently reported from the Atlantic coast of Panama (Martínez et al. 2013), suggest that the diversity of Protodrilus in the Western Atlantic is equivalent to the most studied areas of Europe.

This study focuses on the swash zone of intermediatereflective and reflective beaches. Beaches in this range of morphodynamic states were chosen since they represent the preferred intertidal habitat for Protodrilus, as shown in a previous Brazilian study for a broad range of intertidal habitats (Di Domenico et al. 2009). Each of the species herein described was recorded exclusively at either intermediate-reflective or reflective beaches, and only one species was found at each locality.

Protodrilus pythonius n. sp. was only collected in very coarse sandy sediments at Feiticeira beach, the only reflective sheltered beach presented in the study area. $P$. pythonius is also the only species in the study with long palps with motile ciliary bands and bacillary glands. This palp morphology suggests a major role of the palps in feeding, which may relate to the higher water flow among the larger interstices of coarse-gravelly sandy sediments (Huettel et al. 1996; Riedl et al. 1972; Webb and Theodor 1968). High water flow among interstices decreases organic matter deposition, favoring suspension feeding strategies (Huettel et al. 1996). Protodrilus pythonius possesses long and ciliated palps that are capable of collecting particles in suspension in the larger interstices of its habitat.

In contrast, both $P$. corderoi and $P$. ovarium n. sp. occurred in medium-coarse well-sorted sediments in the more energetic swash zone of exposed intermediatereflective beaches. Protodrilus ovarium was recorded at beaches exposed to southern and southeastern swells, while $P$. corderoi was present at beaches exposed to swells from the east (Alves and Melo 2001; Klein and Menezes 2001). The high turbulence at these environments negatively affects the stability of the superficial layers of sediment but causes oxygenation and constant organic matter input among the grains (Short 1996; McLachlan and Turner 1994). Deposition of the organic matter transported into the sediment in the sub-superficial layers is then increased by the reduced interstices of medium-coarse sediment, with water flow at low Reynolds numbers (Huettel et al. 1996; Riedl et al. 1972; Webb and Theodor 1968). Under those conditions, slender bodies with short palps provided with abundant sensory cilia seem advantageous to explore and detect deposited organic matter in the sub-superficial sediment layers without as easily loosing the inserted palps as if they were longer and densely ciliated.

Remarkably, and as shown in previous studies, the morphological diversity of Protodrilus species is higher among the different habitats surveyed in this study, than 
among similar habitats in different geographical areas (Martínez et al. 2013). P. corderoi and P. ovarium are morphologically similar to $P$. helgolandicus, $P$. hypoleucus, $P$. similis also dwelling in intertidal medium-coarse sand of Europe. Protodrilus pythonius is morphologically closer to P. jägersteni, P. submersus, $P$. litoralis and $P$. smithsoni, which are found in subtidal or intertidal, sheltered areas with coarse sand from New Zeland and Panama (Von Nordheim 1989; Armenante 1903; von Nordheim 1983). These results further indicate that colonization is highly restricted by the specific demands of the environment, and stress the importance of morphological adaptation to different habitats in the evolution of Protodrilus. Future phylogenetic studies of Protodrilus will test whether these shared traits of geographically distant species reflect a radiation of major Protodrilus lineages to similar interstitial habitats or represent multiple convergent adaptations to similar environments among different Protodrilus lineages.

Acknowledgments We thank our colleagues Alexandra Rizzo, Alvaro E. Migotto, Carlos Barbosa, Cinthya S. G. Santos, Fabiane Gallucci, Gustavo Fonseca, Tito C. M. Almeida and technicians and staffs of Marine Biological Section-University of Copenhagen for their generous help and advice. Alessandro L. Prantoni, André Pereira Catani, Reginaldo Nunes, Rômulo Barroso e Veronica Oliveira were most helpful during field sampling. This study was supported by the Brazilian National Council for Technological and Scientific Development (CNPq-Processo 140611/2008-8), which provided the PhD fellowship of MDD, and São Paulo Research Foundation (FAPESPProcesso 2012/08581-0) which provide postdoctoral fellowships and grants for MDD. We are highly indebted to Prof. Angelika Brandt, as well as Kathrin Philipps-Bussau and Petra Wagner, at the Zoologisches Museum of Hamburg and Meziane Tarik, at the Muséum d'Histoire Naturelle, Paris, for the important facilitation of comparison with described species by kindly sending us the relevant type material of Protodrilus spp.

\section{References}

Alves JHGM, Melo E (2001) Measurement and modeling of wind waves at the northern coast of Santa Catarina, Brazil. Braz J Oceanogr 49(1/2):13-28

Armenante Z (1903) Protodrilus hypoleucus n. sp. Monit Zool Ital $14: 221-222$

Bailey-Brock JH, Jouin-Toulmond C, Brock RE (2010) Protodrilidae (Annelida: Polychaeta) from the Hawaiian Islands and comparison with specimens from French polynesia. Pac Sci 64(3): 463-472

Barros F, Borzone CA, Rosso S (2001) Macroinfauna of six beaches near Guaratuba bay, Southern Brazil. Braz Arch of Biol Techn 44:351-364

Boaden PJS (1995) Where Turbellaria? Concerning knowledge and ignorance of marine turbellarian ecology. Hydrobiologia 305(1):91-99

Buchanan JB (1984) Sediment analysis. In: Holme NA, McIntyre AD (eds) Methods to study the marine benthos, vol 16., IPH HandbookBlackwell Scientific Publications, London, pp 41-65
Bush L (1968) Characteristics of interstitial sand Turbellaria: the significance of body elongation, muscular development and adhesive organs. Trans Am Microsc Soc 87(2):244-251

Carvalho JLB, Klein AHF, Schettini CAF, Jabor PM (1996) Marés meteorológicas em Santa Catarina: influência do vento na determinação de parâmetros de projetos para obras costeiras. In: Proceedings of III Simpósio sobre Oceanografia, São Paulo, pp 380

Czerniavsky V (1881) Material ad zoographiam Ponticam comparatam. Fasc. III Vermes. Bulletin de la Société Impériale des naturalistes de Moscou (= Byulletin' Moskovskogo obshchestva ispytatelei prirody) 55(4):211-363

Delamare-Deboutteville C (1960) Biologie des eaux souterraines littorales et continentales. Hermann, Paris, pp 740

Di Domenico M, Lana PC, Garrafoni ARS (2009) Distribution patterns of interstitial polychaetes in sandy beaches of southern Brazil. Mar Ecol 30:47-62

du Bois-Reymond Marcus E (1948) Further archiannelids from Brazil. Comun Zool Mus Hist Nat Montevideo 2:69-83

Folmer O, Black M, Hoeh W, Lutz R, Vrijenhoek RC (1994) DNA primers for amplification of mitochondrial cytochrome $\mathrm{c}$ oxidase subunit I from diverse metazoan invertebrates. Mol Mar Biol Biotechnol 3(5):294-299

Giere O (2009) Meiobenthology. The microscopic motile fauna of aquatic sediments. Springer, Berlin 528

Hatschek B (1880) Protodrilus leuckartii. Eine neue Gattung Archianneliden. Arbeiten aus den Zoologischen Instituten der Universität Wien und der Zoologischen Station in Triest 3(1):79-93

Higgins RP, Thiel H (1988) Introduction to study of meiofauna. Smithsonian Institution Press, Washington, DC

Huettel M, Ziebis W, Forster S (1996) Flow-induced uptake of particulate matter in permeable sediments. Limnol Oceanogr 41(2):309-322

Jägersten G (1952) Studies on the morphology, larval development and biology of Protodrilus. Zooe Bijdr Upps 29:425-512

Jouin C (1970a) Archiannélides interstitielles de Nouvelle-Calédonie. Expédition Française sur les récifs coralliens de la NouvelleCalédonie, 1960-1963. Ed. de la Fondation Singer-Polignac 4:147-167

Jouin C (1970b) Recherches sur les Protodrilidae (Archiannélides): 1. Étude morphologique et systématique du genre Protodrilus. Cah Biol Mar 11:367-434

Jouin C (1992) The ultrastructure of a gutless annelid, Parenterodrilus gen. nov. taenioides (= Astomus taenioides) (Polychaeta, Protodrilidae). Can J Zool 70:1833-1848

Kirsteuer E (1966) Zur kenntnis der Archianneliden des Roten Meeres. Zool Anz 177:288-296

Kirsteuer E (1967) Bredin-Archbold-Smithsonian biological survey of Dominica. 3. Marine archiannelids from Dominica. Proc US Nat Mus 123(3610):1-6

Klein AHF, Menezes JT (2001) Beach morphodynamics and profile sequence for a headland bay coast. J Coast Res 17(4):812-835

Langerhans P (1880) Die wurmfauna Madeiras. II. Z Wiss Zool 33:267-316

Martínez A, Di Domenico M, Jörger K, Norenburg J, Worsaae K (2013) Description of three new species of Protodrilus (Protodrilidae, Annelida) from Central America. Mar Biol Res 9(7): 676-691

McCammon RB (1962) Efficiencies of percentile measures for describing the mean size and sorting of sedimentary particles. J Geol 70(4):453-465

McLachlan A (1985) The biomass of macro- and interstitial fauna on clean and wrack-covered beaches in Western Australia. Estuar Coast Shelf Sci 21(4):587-599 
McLachlan A (1988) Behavioural adaptations of sandy beach organisms: an ecological perspective. In: Chelazzi G, Vannini $M$ (eds) Behavioral adaptation to intertidal life: proceedings of a NATO advanced research workshop on behavioral adaptation to intertidal life, vol 151., NATA ASI Series A Life SciCastiglioncello, Italy, pp 449-475

McLachlan A (1990) Dissipative beaches and macrofauna communities on exposed intertidal sands. J Coast Res 6(1):57-71

McLachlan A, Turner I (1994) The interstitial environment of sandy beaches. Mar Ecol 15(3-4):177-212

Purschke G (1990) Comparative electron microscopy investigation of the nuchal organs in Protodriloides, Protodrilus and Saccocirrus (Annelida, Polychaeta). Can J Zool 68:325-338

Purschke G (1993) Structure of the prostomial appendages and 840 the central nervous system in the Protodrilida (Polychaeta). Zoomorphology 113:1-20

Purschke G, Jouin C (1988) Anatomy and ultrastructure of the ventral pharyngeal organs of Saccocirrus (Saccocirridae) and Protodriloides (Protodriloidae fam. n.) with remarks on the phylogenetic relationships within Protodrilida (Annelida: Polychaeta). J Zool 215:405-432

R Development Core Team (2012) R: a language and environment for statistical computing. R Foundation for Statistical Computing, Vienna, Austria. ISBN 3-900051-07-0, URL http://www.Rproject.org/

Riedl RJ, Huang N, Machan R (1972) The subtidal pump: a mechanism of interstitial water exchange by wave action. Mar Biol 13:210-221

Riser NW (1997) Protodrilus gelderi, a new species of infralittoral, interstitial polychaete from Massachusetts Bay. Proc Biol Soc Wash 110(4):552-557

Ruebush TK (1939) The occurrence of the two rare Genera, Protohydra and Protodrilus, on the east coast of North America. Science 90(2348):617-618
Schettini CAF, Carvalho JL, Truccolo E (1999) Aspectos hidrodinâmicos da enseada da Armação de Itapocoroy, SC. Notas Técnicas da FACIMAR 3:99-109

Short AD (1996) The role of wave height, period, slope, tide range and embaymentisation in beach classification: a review. Rev Chil Hist Nat 69:589-604

Sterrer W (1972) Systematics and evolution within the Gnathostomulida. Syst Zool 21:151-173

Sterrer W (1973) Plate tectonics as a mechanism for dispersal and speciation in interstitial sand fauna. Neth J Sea Res 7:200-222

Struck TH (2011) Direction of evolution within Annelida and the definition of Pleistoannelida. J Zool Syst Evol Res 49(4): 340-345

von Nordheim H (1983) Systematics and Ecology of Protodrilus helgolandicus sp. n., an interstitial polychaete (Protodrilidae) from subtidal sands off Helgoland, German Bight. Zool Scr 12(3):171-177

von Nordheim H (1989) Six new species of Protodrilus (Annelida, Polychaeta) from Europe and New Zealand, with a concise presentation of the genus. Zool Scr 18(3):245-268

Webb JE, Theodor J (1968) Irrigation of submerged marine sands through wave action. Nature 220(5168):682-683

Wentworth CK (1922) A scale of grade and class terms for clastic sediments. J Geol 30:377-392

Westheide W (2008) Polychaetes: interstitial families. The Linnean Society of London and the Estuarine and Coastal Science Association, London, p 152

Wieser W (1957) Archiannelids from the intertidal of Puget Sound. Trans Am Microsc Soc 76(3):275-285

Worsaae K, Kristensen RM (2005) Evolution of interstitial Polychaeta (Annelida). Hydrobiologia 535(536):319-340 